\title{
A retrospective of the research on musical expression conducted at CEGeME
}

\author{
Mauricio A. Loureiro ${ }^{1}$, Tairone N. Magalhães ${ }^{1 *}{\text { Davi A. } \text { Mota }^{1} \text {, Thiago A. M. Campolina }}^{1}$, Aluizio B. O. Neto ${ }^{1}$ \\ ${ }^{1}$ CEGeME - Center for Research on Musical Gesture and Expression - UFMG \\ Av. Antônio Carlos, 6627 - 31270-010, Belo Horizonte, MG \\ \{mauricioloureiro, tairone, davimota, thcampolina, aluizioneto\}@ufmg.br
}

\begin{abstract}
CEGeME - Center for Research on Musical Gesture and Expression is affiliated to the Graduate Program in Music of the Universidade Federal de Minas Gerais (UFMG), hosted by the School of Music, Belo Horizonte, Brazil, since 2008. Focused on the empirical investigation of music performance, research at CEGeME departs from musical content information extracted from audio signals and three-dimensional spatial position of musicians, recorded during a music performance. Our laboratories are properly equipped for the acquisition of such data. Aiming at establishing a musicological approach to different aspects of musical expressiveness, we investigate causal relations between the expressive intention of musicians and the way they manipulate the acoustic material and how they move while playing a piece of music. The methodology seeks support on knowledge such as computational modeling, statistical analysis, and digital signal processing, which adds to traditional musicology skills. The group has attracted study postulants from different specialties, such as Computer Science, Engineering, Physics, Phonoaudiology and Music Therapy, as well as collaborations from professional musicians instigated by specific inquiries on the performance on their instruments. This paper presents a brief retrospective of the different research projects conducted at CEGeME.
\end{abstract}

\section{Introduction}

Aiming at the empirical research on music performance, the Center for Research on Musical Gesture and Expression (CEGeME) was established in 2008, affiliated to the Graduate Program in Music of the Universidade Federal de Minas Gerais (UFMG), directed by Mauricio Alves Loureiro. Hosted by the School of Music of UFMG, at Belo Horizonte, Minas Gerais, Brazil, our laboratories have adequate facilities and equipment for the acquisition and analysis of acoustic data and body movement of musicians, which have been sponsored by grants from Brazilian research funding agencies: $\mathrm{CNPq}$ - National Council of Scientific and Technological Development; FAPEMIG Foundation for Research of the State of Minas Gerais; and CAPES - Foundation for Brazilian postgraduate education. Research at CEGeME departs from musical content information retrieved from performed music, extracted from the audio signal and the three-dimensional spatial position of the musician, recorded during the performance. Analytical models proposed by CEGeME seek to establish a musicological approach to different aspects of musical expres-

\footnotetext{
*Supported by CAPES.
}

siveness by investigating causal relations between the expressive intention of musicians and the way they manipulate the acoustic material, along with how they move while playing a piece of music. The methodology seeks support on knowledge such as computational modeling, statistical analysis and digital signal processing, that adds to traditional musicology skills.

\section{Research}

In 2004, just a few years before the establishment of CEGeME, some of our members conducted research in musical timbre at CEFALA (Center for Research on Speech, Acoustics, Language and Music), a research group located at the School of Engineering of UFMG. They proposed a computational model for representing dynamic timbre variations on the clarinet, using a database of notes performed in four different intensities (pianissimo to fortissimo), covering the whole extension of the instrument $[1,2,3]$. The compelling results from those studies motivated Mauricio Loureiro to proceed in applying computational tools to other problems, and led him to found an interdisciplinary group focused on empirical research on music performance. The group has attracted study postulants from different specialties, such as Computer Science, Engineering, Physics and Phonoaudiology, as well as collaborations from professional musicians instigated by specific inquiries on the performance on their instruments. Over the years, a number of different research projects were conducted at CEGeME. This section presents the CEGeME's projects, which fall into four main categories: (1) Multimodal music information extraction; (2) Empirical study of performed music; (3) Acoustical component of ensemble performance; (4) Sonological applications to music learning and human development.

\subsection{Multimodal music information extraction}

Consists in the development and continuous improvement of tools, algorithms and computational models for extracting acoustic and kinematic parameters from both the audio signal and the three-dimensional spatial position of musicians, to support the requirements of internal research projects.

\subsubsection{Models for extraction and parameterization of musical expressiveness content}

The first research project developed by the group was concerned with the detection of note onsets and the extraction of acoustic descriptors from recordings of clarinet performances $[4,5,6]$. This project culminated in a Matlab tool 
called Expan [7], aimed at extracting variations in note duration, articulation, intensity, pitch, and timbre, among other features, from clarinet recordings. This tool was the outcome of several studies focused on the development of methods for segmenting musical audio signals. It has been essential for proposing and estimating descriptors for the audio parameterization required by the analyses carried by the group. Studies have focused on DSP techniques for the detection of time instants, such as note onsets, note offsets, end of attack, and beginning of release. Methods of automatic segmentation have always been evaluated by comparing output data with manual segmentation. At a certain point, the group developed a prototype graphical user interface to use the tool. Later, we decided instead, to implement a Vamp plugin for Sonic Visualizer/Audacity, containing the algorithms and methods of Expan, capable to provide a straightforward way for comparing parameter values and visualizing data in an interactive graphical interface.

The group is currently working on the development of a Python library called Iracema, which proposes an architecture containing abstractions for the easy manipulation of time series and extraction of information from audio. This tool introduces new methods and techniques, moving towards machine learning models, in order to improve onset detection and obtain more meaningful musical information from audio $[8,9]$.

\subsubsection{Content analysis of note attack and note transitions in music performance}

Characteristics related to the quality of the transitions between consecutive notes are decisive in the construction of an interpretation. They are manipulated by the performer by controlling note durations and the quality of attacks and note groupings. Studies on this project focus on the modelling of what happens in the transient region when notes are initiated, as well as in the time interval situated between consecutive notes of a musical sentence $[10,11,12,13]$. Description of note attack transients also explored the harmonic content of reverberation independently from the note being played, which allows inferences about the musician's interaction with room acoustics $[14,15]$.

\subsubsection{Segmentation and parameterization of musician's physical gesture}

Studies concerned on the extraction of information from musician's body movement, while playing their instruments. Three-dimensional spatial position of their body and instruments are tracked by two high-end 3D motion capture devices: a more accurate with active infrared markers (Optotrak Certus), and a more versatile with passive infrared markers (Optitrack Motive/Flex3). Techniques were developed for processing and segmenting movement data, based on statistical, geometrical, temporal and musical aspects, aiming at developing methodologies for multimodal parametric analysis of music performance, integrating musician's physical gestures information to acoustical parameters extracted from audio. [16, 17, 18, 19, 20].

\subsection{Empirical study of performed music}

Focusing on different aspects of musical expressiveness, these projects propose analytical models that seek to identify causal relations between the expressive intention of musicians and the way in which they manipulate the acoustic material and how they move when interpreting a musical work.

\subsubsection{Individuality, consistency and diversity of music performances}

Studies in the realm of this project focus on analyzing the dynamics of acoustic and gestural parameters observed during music performances, aiming to characterize traits related to individual style, i.e., common aspects shared by different performances played by the same musician [21]. These studies can be used to support models for individuals discrimination (the automatic recognition of performers) as well as for characterization of performance style $[22,23,24]$. Considering that temporal variations are the acoustic manipulations that most stand out in the perception of the expressive quality of an interpretation of a score of traditional classical repertoire, some studies focused on the fluctuation of temporal proportions of rhythmic structures produced by the interpreter, to investigate its potential for characterizing such expressive manifestations [25, 26]. As the relevance of expressive manipulations may shift to other types of acoustic parameters for the characterization of individuality, depending on factors such as genre and cultural context, another study focused on pitch manipulations of bendings and vibratos on the electric guitar. The results showed a remarkable consistency within performances by the same guitarist, but still with substantial diversity when comparing different performers. [24, 27].

\subsubsection{Body movement in music performance: role and meaning}

This project comprises studies focused on the hypothesis that body movements executed by musicians during performances are closely related to their sounded expressive intentions according to their understanding of the musical structure they interpret. Sophisticated recurrence analysis of body movement patterns, identified in different performances of the same music, revealed that musicians execute gestures patterns recurrently associated to higher expressive content dictated by outstanding elements of the musical structure, such as melodic phrasing, score dynamic markings, rhythmic and harmonic transitions $[28,29,30,31]$. Studies in the realm of this project also showed evidences that musician's gestures reflect musical phrase organization [32], as well as that body movement during music performances carries enough information for recognizing the interpreter [23].

\subsection{Interaction and coordination in ensemble music performance}

Aimed at investigating the synchronization/coordination process in small musical ensembles, projects in this category attempt to model musician's interactions in typi- 
cal performance scenarios, using visual and acoustical responses collected during real musical performances simulations. Patterns of temporal synchronization and/or other coupling patterns, manifested through sound manipulations and body movements, were observed and analyzed, in order to map acoustic and gesture-related elements that could influence the adjustment between musicians.

\subsubsection{Acoustical component of ensemble performance}

This topic addresses the temporal synchronization between musicians, the dynamics of the interaction between leaders and followers and how it may influence the coordination of ensembles. In ensemble performances, musicians share the responsibility of shaping the sounds, either by serving as a reference for other players (e.g. a conductor) or by following the cues indicated by the ensemble leader. The dynamics of this interaction seems to extends beyond the temporal synchronization, encompassing multiple dimensions of the musical domain, for instance, as we observed that flute players tend to modify their timbre when following a clarinet or a bassoon with consistently different tendencies for each instrument [33, 34, 32]. Another central question of these studies is how musicians can become effective in performing such coordinated actions, either when they play as leaders or as followers. According to a known hypothesis of cognitive psychology, the act of anticipating the effects of other peoples' actions may be in the center of the coordination process. One consequence of this hypothesis is that if internal models formed in previously performed actions are applicable to current actions, musicians should be better in predicting the results of their own recorded actions than the results of actions performed by others [35]. Our studies corroborate this hypothesis by demonstrating that musicians have better chance of synchronizing with their own previously recorded performances $[36,37,38]$.

\subsubsection{Gestural component of ensemble performance}

The focus is on the gestural interactions between musicians during ensemble performance. Recurrent patterns of body/instrument movements are identified in an attempt to map acoustical responses to gesture-related elements that could influence the adjustment between musicians. While verifying the relationship of musician's body movements to their expressive intentions during the performance, we were able to identify information patterns recurrent enough for recognizing who played the excerpt, which we call "gestural signatures". We also observed that these signatures were disturbed, when musicians followed recordings. Moreover, disturbances were smaller when musicians followed recordings made by themselves, even without visual contact between co-performers [39, 40].

\subsubsection{Multimodal interactions in ensemble performance}

Studies regarding the inherent multimodal complexity in music ensemble interactions, which uses complementary approaches involving the analysis of kinematic and acoustic parameters as a way to model human-to-human musical interactions by combining the multiple dimensions that are enrolled in the process of creating collaborative musical performances [41, 37, 42].

\subsection{Sonological applications to music learning and human development}

It takes as object of investigation the human behavior in musical activities mediated by technological tools directed to learning and human development.

\subsubsection{Multimodal data analysis in musical expertise development}

Several tools for analyzing multimodal data extracted from music performance are currently being developed and advancements in this area evolve in an astonishing pace. This project investigates how such techniques can be used on the refinement of the expertise and skill development by students, teachers and professional musicians. A Master Thesis investigated left hand position shifting technique on the double bass, relating kinematic and acoustic information [43]. Timbre descriptors were used to verify timbre modification due to coupling interpretation in ensemble performance of different instruments [33]. An attempt was made to use the outcome of this study on the construction of a flute-bassoon duo performance [34]. The potentials indicated by these studies motivated further investigation on the interaction of musical practice in a classroom setting with audio analysis tools [44]. A PhD Thesis reported methods and results for this interaction, occurred on Weekly clarinet classes, in which the master and his class were recorded and analyzed, as extracted musical information were used as feedback for both teacher and students [45]. Another thesis conducted by an accomplished oboist focused the relationship of oboe reed scraping and sound quality and sound emission techniques. In 2015 an harpist joined CEGeME willing to investigate what role musical gesture plays on helping the performer to organize the expressive ideas behind his/her playing. She began her work by inquiring how feedback can aid the development of metacognitive skills for music performance [46, 44] and later delved into understanding how this process occurs with undergraduate level students [47] and [48]. A professional clarinetist, member of one of the most prominent Brazilian symphony orchestras is currently delving into the relationship between clarinetists' gestures and the quality of the legato. He conducts computational analysis of sound and fingers' movement acquired from a series of experiments with a number of professional musicians, using motion capture devices and high quality audio recording. $[49,50]$. Two master dissertations are on the first stages of development within this project. One deals with didactic approaches regarding the use of valves on the bass trombone [51], and the other investigates the relationship between airflow speed and sound quality in trumpet playing [52].

\subsubsection{Sonological Applications to Human Development}

The first half of the twentieth century gave birth to a sonic revolution, consequence of the invention of devices capable of recording and playing back sounds, allowing for 
novel ways of investigating how humans respond to and act through sound. Within the domains of this project we seek to understand human conditions and practices through its relation to sound and sonology-related themes in general. Most of the work presented here is related to health and well-being, where music-therapy plays a prominent and increasingly important role. A Master project sought to adapt the Nordoff Robbins Musical Communicativeness Scale to the Brazilian context, evaluating cultural and linguistic issues related to its use. The scale is used in the USA since the 1960's to evaluate behaviors from sound and musical stimuli through vocalizations, manipulation of musical instruments and body movement. The analysis of 24 music therapy methodological videos was adopted for boardline cases' people with neurodevelopmental disorders. One researcher and four invited examiners have participated in this study stage. The inter-examiner scores have presented moderate and strong correlations (Spearman), indicating evidences of reliability for the Brazilian version of the scale. $[53,54,55,56]$. The dissertation led to an ongoing $\mathrm{PhD}$ project [57], in which the relationship between Pierre Schaeffer's modes of listening and the Nordoff Robbins Scales is being studied[58]. A musical game was proposed in a Master project in order to investigate expressive behaviour in children suffering from disorders within the autism spectrum, which proposed 12 principles and strategies and 7 recommendations for games researchers $[59,60,61]$. Two master projects are being developed, on behavioral evaluation of premature babies in response to sound stimuli [62] and on how music can help with arm abduction in people with cerebral palsy.' [63].

\section{Workshops and scientific events}

\subsection{Human movement and music: capture, representation, analysis}

The seminar was held at the School of Music of UFMG, on June 7th and 8th, 2017. Invited researchers from local and international institutions, as well as collaborators of CEGeME presented lectures, recitals, and conducted seminars and workshops [64]:

- Carolina Brum Medeiros from the Input Devices and Music Interaction Laboratory (IDMIL), School of Music, McGill University, Montreal, conducted a workshop, "Motion Capture - solutions for specific issues at a motion capture laboratory", and presented the lecture "Processing and analysis of human movement - methodological strategies for the processing and analysis of human movement".

- Hani Camille Yehia, director of the Center for Research on Speech, Acoustics, Language and Music (CEFALA), School of Engineering, Federal University of Minas Gerais (UFMG) presented the lecture "Comparative Analysis of Techniques of Acquisition and Representation of the Human Movement".

- Luiz Bavaresco de Naveda, School of Music, State University of Minas Gerais (UEMG) conducted a workshop, "Analysis of cross-modal patterns through estimation of directional changes density applied to musical movement".

- André Cavazotti e Silva, School of Music, Federal University of Minas Gerais (UFMG) presented a report about the work in progress for a performance involving the body movement of a violinist with video capture, "The flight of Tchiurubibirú in search of the first movements".

The seminar ended with a discussion panel on the research projects conducted at CEGeME involving the invited researchers, follwed by a harp recital performed by Aricia Marques Ferigato, a PhD student at CEGeME.

\subsection{Musical expressiveness descriptors: meaning and applications}

Inspired by the festival "Pint of Science", this event consisted in a lecture held at Restaurante Novo Paladar, in Belo Horizonte, across the street of UFMG Campus, on June 21st, 2017 [65], presented by Jônatas Manzzolli, former irector of the Interdisciplinary Nucleus of Sounding Communication (NICS), Institute of Arts, State University of Campinas (UNICAMP) and visiting professor at the Center for Autonomous Systems and Neuro-robotics (NRAS), Pompeu Fabra University, Barcelona, Spain.

Manzzolli presented a research project on interfaces and devices in an immersive laboratory for generating information from motion, image and sound with potentials strategic applications for the study of musical expressiveness, in its interpretative and creative aspects. Iannis Xenakis's on music motivated the debate that followed the lecture: "I do not think that any attempt to consider music as a language can be successful. The substructure of music is much closer to the substructure of space and time. Music is purer and much closer to the categories of the mind."

\subsection{Technical and learning aspects of clarinet and bass clarinet: sonority, articulation, extended technique}

Held at the School of Music of UFMG, on October 2017 [66], the seminar had as special guest, the renowned Brazilian clarinetist Luis Afonso Montanha, of the Music Department of the University of São Paulo (USP), former first clarinetist of the Municipal Symphony Orchestra of São Paulo and the Symphonic Jazz Orchestra of the State of São Paulo, winner of several national and international Music Prize.

- Montanha, together with the permanent clarinetists of Philharmonic Orchestra of Minas Gerais, Alexandre Silva, Ney Franco and Marcus Julius Lander, conducted a discussion panel on sound emission (timbre and tuning) and articulation (attack, legato, staccato) on the clarinet.

- These same artists participated on the Seminar Processes of understanding and awareness on clarinet and bass clarinet learning, coordinated by Aluizio Barbosa de Oliveira Neto, a research member of CEGeME, PhD 
candidate at the time. The seminar proposed experiments on empirical analysis of clarinet performances, aimed at discussing possible contribution of parametric feedback to the development of skills related to aspects of sound emission, such as sound quality and tuning, as well as of the execution of different types of note articulation, such as legato and staccato.

- Montanha also gave a clarinet and bass clarinet Masterclass with emphasis on contemporary repertoire and extended techniques and presented the lecture, Extended technique on bass clarinet and the relation between composer and performer in the development of a musical work.

\subsection{1th International Conference of Students of Systematic Musicology (SysMus)}

On June 2018, CEGeME hosted the 11th International Conference of Students of Systematic Musicology (SysMus), which happened for the first time in Latin America, in the city of Belo Horizonte, and received 60 submissions from from 47 universities and institutes around the world [67]. The event was attended by more than 60 participants, from 10 different countries, and included three speeches by prominent researchers in the field.

- Juan Pablo Bello, associate professor of Music Technology and Computer Science \& Engineering at New York University - "Some Thoughts on the How, What and Why of Music Informatics Research"

- Andre Holzapfel, assistant professor at the Media Technology and Interaction Design department at KTH Royal Institute of Technology in Stockholm, working in the area of Sound and Music Computing (SMC) "Computer-aided studies of rhythm and meter and the impact of ethnocentric bias"

- Mauricio Alves Loureiro, director of CEGeME and full professor of music at the Federal University of Minas Gerais (UFMG) - "Systematic Musicology: a perspective from the musical signal"

\section{Artistic events}

In 2015, some of the members of our group gave birth to the NA/CEGeME, an artistic group aiming to put into practice the technical knowledge generated by the laboratory activities through art. Three performances were developed: ApropriaAção [68], Espaço, Fluxo e Transcendência [69] and Subverta [70]. The pieces were intended to arouse different sensibilities, transforming sites located in a grove at the university campus into an artistic space.

\subsection{ApropriAção}

ApropriAção was intended to transform places that until then carried out various functions into artistic spaces, presenting performances that involve different aspects of human perception. Visual projections were used as a way to contribute to the sonic environment created by the musicians during the performance, producing sounds and images computationally modulated by the movements and responses from the audience.

\subsection{Espaço, Fluxo e Transcendência}

In this performance, the woods in front of the School of Music of UFMG were transformed into a space of sound and visual interaction. The public was encouraged to traverse paths where, through their own movement, they were able to manipulate the acoustic material generated by the various performances taking place on the audience surroundings. Immersed in sound and guided by it, the flow of people also controlled the visual projections that illuminate the possible paths. Sounds and images resulting from the combined action between artists and public emerge from the woods and are responsible for the resulting experienced environment.

\subsection{SubvertA!}

In a happening entitled SubvertA!, CEGeME's Artistic Group entices the audience to engage on novel experiences with their surroundings. Through aesthetic fruition and by promoting the creative use of public spaces, NA/CEGeME developed performances involving different aspects of human perception. Threaded by music, sound, visual projections and multisensory interactions, SubvertA! promotes a challenge to the experience of university spaces, seeking to strengthen resistance to actions that inhibit and discourage the creative use of the campus, converging with other sociopolitical and cultural manifestations and occupation policies in the urban context. Audio processing tools and techniques for motion analysis developed at the CEGeME Lab were used to create the audio/visual landscape and interactive devices that allowed for this experience.

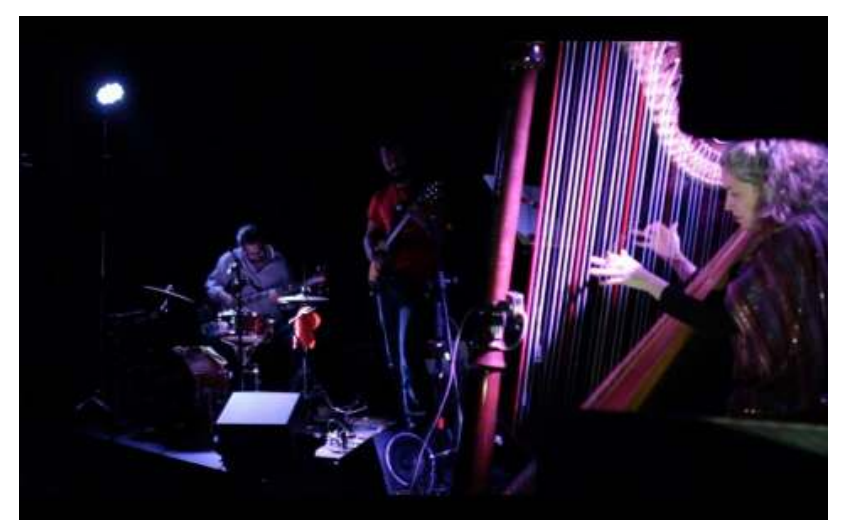

Figure 1: NA/CEGeME performing in 2017.

\section{Future perspectives}

Results of CEGeME research show potentials to broaden the perception of musical expressiveness content, which could be directed to the daily musical practice of instrumentalists and singers, that could contribute to the development of performance excellence, as well as to be used as pedagogical resource in musical instrument and singing lessons. From this perspective, we envisage in CEGeME the development of an appropriate platform that can offer professional musicians, teachers and instrumentalist students an interactive interface that demands low training investment from the user in order to provide a simpler and 
more comfortable tool for the empirical research of musical performance, aiming at facilitating the use by a greater number of users and for a greater volume of data. We believe that such a tool, properly tested and validated in a real situation of practice and musical pedagogy, should present great potential of application in different contexts of the practice and the teaching of music. The results of this project and possible resources produced by it may also arouse interest in research in other areas of music, such as interactive composition, music education and music therapy, as well as other arts such as theater, dance and art education.

\section{Acknowledgements}

CEGeME projects are made possible with the sponsorship of the National Council for Scientific and Technological Development - CNPq and the Foundation for Research of the State of Minas Gerais - FAPEMIG.

\section{References}

[1] Hugo B. Paula, Hani C. Yehia, J. A. Vasconcelos, and Mauricio A. Loureiro. Representing timbre dynamics of a musical instrument: Comparison between GA and PCA. In Machine Learning for Signal Processing XIV - Proceedings of the 2004 IEEE Signal Processing Society Workshop, 2004.

[2] Mauricio A. Loureiro, Hugo B. Paula, and Tairone N. Magalhães. Modelagem da variação do timbre musical utilizando modelos auditivos e mapas de Kohonen. In I Encontro Nacional de Cognição e Artes Musicais, pages 156163, Curitiba, 2006.

[3] Mauricio A. Loureiro and Hugo B. Paula. Timbre de um instrumento musical: caracterização e representação. Per Musi - Revista Acadêmica de Música, 14:57-81, 2006.

[4] Mauricio. A. Loureiro, Tairone N. Magalhães, Rodrigo C. Borges, Thiago A. M. Campolina, Davi A. Mota, and Hugo de Paula. Segmentação e extração de descritores de expressividade em sinais musicais monofônicos. In III Seminário Música Ciência e Tecnologia, pages 109-125, 2008.

[5] Mauricio. A. Loureiro, Rodrigo C. Borges, Thiago A. M. Campolina, Tairone N. Magalhães, Davi A. Mota, and Hugo De Paula. Extração de conteúdo musical em sinais de áudio para análise de expressividade. In Anais do XVII Encontro da Sociedade Brasileira de Acústica SOBRAC, pages 146-152, Belo Horizonte, 2008.

[6] Mauricio A. Loureiro, Tairone N. Magalhães, Rodrigo C. Borges, Thiago A. M. Campolina, Davi A. Mota, and Hugo B. de Paula. Segmentação automática de sinais musicais monofônicos para análise da expressividade. In Congresso da Associação Nacional de Pesquisa e PósGraduação (ANPPOM), pages 334-340, 2008.

[7] Thiago A. M. Campolina, Davi A. Mota, and Mauricio A. Loureiro. Expan: a tool for musical expressiveness analysis. In Proceedings of the 2 nd International Conference of Students of Systematic Musicology, pages 24-27, 2009.

[8] Tairone N. Magalhães. Computational Tools and Methods for the Empirical Study of Monophonic Music Performance. Ongoing PhD Thesis, Universidade Federal de Minas Gerais, 2019.

[9] Willy G. Cornelissen. Onset detection in silico. Ongoing Master Thesis, Universidade Federal de Minas Gerais, Belo Horizonte, Brazil, 2019.
[10] Mauricio A. Loureiro, Hani C. Yehia, Hugo B. Paula, Thiago A. M. Campolina, and Davi A. Mota. Content analysis of note transitions in music performance. In Proceedings of the 6th Sound and Music Computing Conference, SMC 2009, pages 355-359, 2009.

[11] Mauricio. A. Loureiro, Davi A. Mota, Thiago A. M. Campolina, Euler C. F. Teixeira, Hugo Bastos De Paula, and Hugo B. Paula. O Som entre as Notas: Representação das Transições entre as Notas em Instrumentos Monofônicos. In Anais do XIX Congresso da Associação Nacional de Pesquisa e Pós-Graduação em Música, pages 581-585, 2009.

[12] Thiago A. M. Campolina. Estudo sobre Transientes em Sinais de Fala e Música. Master thesis, Universidade Federal de Minas Gerais, 2012.

[13] Rodrigo C. Borges. Um Estudo sobre Classificações Físicas e Perceptivas de Timbres da Escuta Cotidiana, de Sons Sintetizados e de Noise Music. Master dissertation, Universidade Federal de Minas Gerais, 2013.

[14] Thiago A. M. Campolina and Mauricio A Loureriro. Description of Monophonic Attacks in Reverberant Environments via Spectral Modeling. In Paper submitted to Computer Music Multicisciplinary Research Conference, Marseille, France, 2019., Marseille, France, 2019.

[15] Campolina, Thiago A. M. Detecção, análise espectral e caracterização de ataques em instrumentos monofônicos. Ongoing $\mathrm{PhD}$ Thesis, Universidade Federal de Minas Gerais, 2019.

[16] Hugo B. Paula, Euler C. F. Teixeira, Raphael A. V. Borges, and Mauricio A. Loureiro. Automatic Gesture Segmentation of a Music Performance Using a Cumulative Dissimilarity Measure. In Brazilian Symposium on Computer Music, number 2005, pages 13-24, 2015.

[17] Euler C. F. Teixeira. Análise Quantitativas da Expressividade Musical com Base em Medidas Acústicas e do Gesto Físico. Master dissertation, Universidade Federal de Minas Gerais, 2010.

[18] Euler C. F. Teixeira, Hani C. Yehia, and Mauricio A. Loureiro. Aspectos metodológicos da Pesquisa em Expressividade Musical a partir de Informação de Movimento Corporal. In Anais do XX Congresso da Associação Nacional de Pesquisa e Pós-Graduação em Música, pages 1364-1370, 2010.

[19] Euler C. F. Teixeira, Hani Camille Yehia, Mauricio A Loureriro, and Marcelo Wanderley. Motion recurrence analysis in music performances. In SMC Proceedings of Sound and Music compouting Conference 2013, number August, pages 317-322, Stockholm, Sweden, 2013. KTH.

[20] Euler C. F. Teixeira. Motion analysis of clarinet performers. $\mathrm{PhD}$ thesis, Universidade Federal de Minas Gerais, 2014.

[21] Tairone N. Magalhães, Davi A. Mota, and Mauricio A. Loureiro. A individualidade musical na performance: conceitos teóricos, estratégias metodológicas e perspectivas. In Anais do $13^{\circ}$ Simpósio de Cognição e Artes Musicais - SIMCAM 13, pages 270-277, Curitiba, Brazil, 2017.

[22] Gabriel P. Pezzini, Thiago A. M. Campolina, and Mauricio. A. Loureiro. Stochastic Modeling of Expressiveness: Representing the Temporal Evolution of the Descriptors Using HMM Modeling. In SysMus14 - International Conference of Students of Systematic Musicology, pages 1-4, 2014.

[23] Davi A. Mota, Mauricio A. Loureiro, and Rafael Laboissière. Identificação do intérprete a partir de 
informação de movimento corporal. Anais do XIX Congresso da Associação Nacional de Pesquisa e PósGraduação em Música, 2014.

[24] Tairone N. Magalhães. Análise do bending e do vibrato na guitarra elétrica a partir dos descritores de expressividade da ferramenta Expan. Master thesis, Universidade Federal de Minas Gerais, 2015.

[25] Mauricio A. Loureiro and Davi A. Mota. Caracterização Paramétrica da Agógica na Interepretação Musical. In XXVIII Congresso da Associação Nacional de Pesquisa e Pós-Graduação em Música - Manaus - 2018, pages 110. ANPPOM - Associação Nacional de Pesquisa e PósGraduação em Música, 2018.

[26] Mauricio A. Loureiro. Uniformidade e Diversidade em Execução Musical: mesa redonda da ANPPOM discute a agógica. In Sonia Regina Albano de Lima and Martha Tupinambá de Ulhôa, editors, ANPPOM: 30 Anos de Criação, pages 72-89. ANPPOM - UDESC, Florianópolis, 2018.

[27] Tairone N. Magalhães, Davi A. Mota, Aluizio B. O. Neto, Mauricio A. Loureiro. Análise do vibrato e bending na guitarra elétrica. In Anais do XV Simpósio Brasileiro de Computação Musical, pages 36-47, 2015.

[28] Euler C. F. Teixeira, Hani C. Yehia, and Mauricio A. Loureiro. Relating movement recurrence and expressive timing patterns in music performances. Journal of the Acoustical Society of America, 138(3), 2015.

[29] Euler C. F. Teixeira, Mauricio A. Loureiro, Marcelo M. Wanderley, and Hani C. Yehia. Motion Analysis of Clarinet Performers. Journal of New Music Research, 44(2):97111, 2015.

[30] Euler C. F. Teixeira and and Hani C. Yehia Mauricio A. Loureiro. Linking movement recurrence to expressive patterns in music performance. In Micheline Lesaffre, Marc Leman, and Pieter-Jan Maes, editors, The Routledge Companion to Embodied Music Interaction, pages 380387. Routledge Taylor \& Francis Group, New York, 2017.

[31] Euler C. F. Teixeira, Mauricio A. Loureiro, and Hani C. Yehia. Expressiveness in Music From a Multimodal Perspective. Music Perception: An Interdisciplinary Journal, 36(2):201-216, dec 2018.

[32] Thaís F. Santos. The relationship between ancillary gestures and musical phrase organization: application to flute performance. Phd thesis, Universidade Federal de Minas Gerais, 2017.

[33] Thais F. Santos, Aluizio B. O. Neto, and Mauricio A. Loureiro. Musical communication of flutists in ensemble performance. In 7th International Conference of Students of Systematic Musicology (SysMus14), pages 1-5, London, 2014.

[34] Thaís F. Santos, Raquel S. Carneiro, Aluizio B. O. Neto, and Mauricio A. Loureiro. Construção de uma performance em conjunto a partir de um estudo de parâmetros acústicos. In Associação Nacional de Pesquisa e Pós-Graduação em Música, 2015.

[35] G. Knoblich and R. Flach. Predicting the effects of actions: Interactions of perception and action. Psychological Science, 12(6):467-472, 2001.

[36] Rafael Laboissière, Davi A. Mota, Thiago A. M. Campolina, Hani C Yehia, and Mauricio A. Loureiro. Evidence for Self-Other Effects and Structure-Related Attentional Mechanisms in the Primo/Secondo Performances of Clarinetists. In UFMG, editor, Proceedings of the 16th International Conference on Perception and Action (ICPA 2011), Ouro Preto, Minas Gerais, Brazil, 2011.
[37] Davi A. Mota. Análise dos padrões de sincronização em duos de clarineta a partir de parâmetros acústicos e cinemáticos. Master dissertation, Universidade Federal de Minas Gerais, 2012.

[38] Mauricio A. Loureiro, Davi A. Mota, Thiago A. M. Campolina, Hani C. Yehia, and Rafael Labiossière. Acoplamento interpretativo e sincronização em duos de clarinetas. OPUS, 18(2):181-206, 2012.

[39] Davi A. Mota, Mauricio A. Loureiro, and Rafael Laboissière. Influence of expressive coupling in ensemble performance on musicians' body movement. In Proceedings - 40th International Computer Music Conference, ICMC 2014 and 11th Sound and Music Computing Conference, SMC 2014 - Music Technology Meets Philosophy: From Digital Echos to Virtual Ethos, number September, pages 513-519, Athens, Greece, 2014. The National and Kapodistrian University of Athens.

[40] Davi A. Mota, Mauricio A. Loureiro, and Rafael Laboissière. Gestural interactions in ensemble performance. Routledge Taylor \& Francis Group, New York, 2017.

[41] Davi A. Mota, Mauricio A. Loureiro, and Rafael Laboissière. Analysis of synchronization patterns in clarinet duos using acoustic and kinematic parameters. In Favio Shifres, María Jacquier, Daniel Gonnet, María Inés Burcet, and Romina Herrera, editors, Actas de ECCoM. Vol. 1 Nol, "Nuestro Cuerpo en Nuestra Música. 11o ECCoM", volume 1, pages 199-206, Buenos Aires, 2013. SACCoM.

[42] Davi A. Mota. Multi-modal coupling in musical performance. Phd thesis, Universidade Federal de Minas Gerais, 2017.

[43] Giordano C. O. M. Cornelio. Análise acústica e cinemática da técnica de mudança de posição no contrabaixo acústico. Master's thesis, 2013.

[44] Aluizio B. O. Neto, Arícia Ferigato, Thiago A. M. Campolina, Ravi S. V. Domingues, and Mauricio A. Loureiro. Ferramentas de análise empírica e metacognição no processo de interpretação musical. Anais do XII Simpósio Internacional de Cognição e Artes Musicais, pages 250-257, 2016.

[45] Aluizio B. O. Neto. Rumo à sala de estudos aumentada: Experiências com suporte computacional para o desenvolvimento técnico e perceptivo na performance musical. Phd thesis, Universidade Federal de Minas Gerais, 2018.

[46] Arícia Ferigato and Mauricio A. Loureiro. Imagética musical e metáfora como recurso ativador/indutor do gesto corporal na interpretação e na performance musical. In Anais do XIII Simpósio Internacional de Cognição e Artes Musicais, pages 287-293, curitiba, PR, Brazil, 2017. UFPR.

[47] Arícia Ferigato and Mauricio A. Loureiro. Gesto corporal e conteúdo expressivo na construção da performance musical de alunos de harpa. In XXVIII Congresso da Associação Nacional de Pesquisa e Pós-Graduação em Música - Manaus - 2018, pages 1-7. ANPPOM - Associação Nacional de Pesquisa e Pós-Graduação em Música, 2018.

[48] Aricia M. Ferigato. Construção da performance na harpa de pedais: relações entre gesto corporal e conteúdo expressivo musical. Ongoing $\mathrm{PhD}$ Thesis, Universidade Federal de Minas Gerais, Belo Horizonte, Brazil, 2019.

[49] Alexandre P. Silva. Estudo do legato na clarineta através de parâmetros acústicos e cinemáticos do movimento dos dedos. Ongoing $\mathrm{PhD}$ Thesis, Universidade Federal de Minas Gerais, Belo Horizonte, Brazil, 2019.

[50] Alexandre P. da Silva. Captura dos movimentos dos dedos de clarinetistas: descrição dos processos metodológicos. In 
Anais do IV Simpósio Brasileiro de Pós-Graduandos em música, pages 1095-1104, Rio de Janeiro, RJ, 2016.

[51] Renato R. Lisboa. O uso das válvulas do trombone baixo: questões técnicas do instrumento e suas consequências no repertório, performance e abordagens didáticas. Ongoing Master Thesis, Programa de Pós-Graduação em Música Universidade Federal de Minas Gerais, Belo Horizonte, Brazil, 2019.

[52] Gustavo M. Oliveira. Influência da velocidade do fluxo de ar na sonoridade do trompete. Ongoing Master Thesis, Universidade Federal de Minas Gerais, Belo Horizonte, Brazil, 2019.

[53] Aline M. André; Cristiano M. A. Gomes; Cybelle M. V. Loureiro. Reliability inter-examiners of the nordoff robbins musical communicativeness scale brazilian version. 2018.

[54] Aline M. André; Cristiano M. A. Gomes; Cybelle M. V. Loureiro. Equivalência de itens, semântica e operacional da versão brasileira da escala nordoff robbins de comunicabilidade musical. OPUS, 23(2):197-215, 2017.

[55] Aline M. André, Cristiano M. A. Gomes, and Cybelle M. V. Loureiro. Escalas nordoff robbins: uma revisão bibliográfica. Percepta-Revista de Cognição Musical, 3(2):117, 2016.

[56] Aline M. André. Tradução e validação da Escala Nordoff Robbins de Comunicabilidade Musical. Master dissertation, 2017.

[57] Aline M. André. Tradução e Validação das Escalas Nordoff Robbins: "Relação Criança Terapeuta na Experiência Musical Coativa" e "Musicabilidade, Formas de Atividade, Estágios e Qualidades de Engajamento". Ongoing $\mathrm{PhD}$ Thesis, Programa de Pós-Graduação em Música Universidade Federal de Minas Gerais, 2019.

[58] Aline M. André and Cybelle M. V. Loureiro. Modos da escuta de pierre schaeffer e escalas nordoff robbins: um estudo de caso. In Congresso da Associação Nacional de Pesquisa e Pós-Graduação (ANPPOM), 2019.

[59] Débora L. Gomes and Cybelle Loureiro. Proposta de um aplicativo na hipersensibilidade sonora no autismo. XIII SIMCAM-Simpósio Internacional de Cognição e Artes Musicais, 22(2005):8, 2017.

[60] Débora L. Gomes and Cybelle Loureiro. Aplicativo musical na hipersensibilidade sonora nos transtornos do neurodesenvolvimento: Um estudo de revisão, 2017.

[61] Debora L. Gomes. Musical App in Hypersensitivity to Sounds and Neurodevelopmental Disorders: Applicable Strategies. Master Thesis, Programa de Pós-Graduação em Música Universidade Federal de Minas Gerais, 2018.

[62] Rhainara L. C. Ferreira. Validação De Um Protocolo De Avaliação Comportamental De Bebês Prematuros Em Resposta A Estímulos Sonoros. Ongoing Master Thesis, Programa de Pós-Graduação em Música Universidade Federal de Minas Gerais, 2019.

[63] Emily H. P. Ferreira. Como a música pode auxiliar na abdução de braços em pessoas com Paralisia Cerebral. Ongoing Master Thesis, Programa de Pós-Graduação em Música Universidade Federal de Minas Gerais, 2019.

[64] Thais F. Santos Aluizio B. O. Neto, Arícia M. Ferigato; Davi A. Mota and Mauricio A. Loureiro. Seminar: Human Movement and Music: capture, representation, analysis. School of Music of the UFMG, June 2017.

[65] Jônatas Manzzolli. Musical expressiveness descriptors: meaning and applications. Restaurante Novo Paladar, Av. Antônio Abrahão Caran, 764 - Pampulha, June 2017.
[66] Luis A. Montanha. Seminar: Technical and learning aspects of clarineta and bass clarinet: sonority, articulation, extended technique. School of Music of the UFMG, October 2017.

[67] SysMus18. In Tairone N. Magalhães and Davi A. Mota, editors, Proceedings of the 11th International Conference of Students of Systematic Musicology, 2018.

[68] NA/CEGeME Group. Performance ApropriAção. 47o Festival de Inverno da UFMG, july 2015. [www.ufmg.br/festivaldeinverno/2015/eventos; www.youtube.com/watch?v=1V0Iv3ZnyGw; accessed 31-Maio-2019].

[69] NA/CEGeME Group. Performance Espaço, Fluxo e Transcendência. 48o Festival de Inverno da UFMG, july 2016. [www.ufmg.br/festivaldeinverno/2016/eventos; accessed 31-Maio-2019].

[70] NA/CEGeME Group. Performance Subverta. 49o Festival de Inverno da UFMG, july 2017. [www.ufmg.br/festivaldeinverno/2017/eventos; www.youtube.com/watch?v=fMQUvOb52Ac; accessed 31-Maio-2019]. 